\title{
Climate Change Adaptability of Farmers: Malaysian Case Study
}

\author{
Md. Mahmudul Alam * \\ PhD Student \\ Institute for Environment and Development (LESTARI) \\ National University of Malaysia (UKM), Malaysia \\ E-mail: rony000@gmail.com \\ Chamhuri Siwar \\ Emiretus Professor \\ Institute for Environment and Development (LESTARI) \\ National University of Malaysia (UKM), Malaysia \\ E-mail: csiwar@ukm.my
}

\author{
Abdul Hamid Jaafar \\ Professor \\ Faculty of Economics and Management \\ National University of Malaysia (UKM), Malaysia \\ E-mail: ahamid@ukm.my \\ Basri Talib \\ Associate Professor \\ Faculty of Economics and Management \\ National University of Malaysia (UKM), Malaysia \\ E-mail: basri@ukm.my \\ Khairulmaini Bin Osman Salleh \\ Professor and Head of Department \\ Department of Geography \\ University of Malaya, Malaysia. \\ Email: khairulmaini@gmail.com
}

*corresponding author

\section{Citation Reference:}

Alam, M.M., Siwar, C., Jaafar, A.H., Talib, B., and Salleh, K.O. 2013. Climate Change Adaptability of Farmers: Malaysian Case Study. International Journal of Plant, Animal and Environmental Sciences, 3(3): 130-135. Available at http://www.ijpaes.com/admin/php/uploads/366 pdf.pdf

This is a pre-publication copy.

The published article is copyrighted by the publisher of the journal. 


\title{
Climate Change Adaptability of Farmers: Malaysian Case Study
}

\begin{abstract}
The climatic factors are changing very rapidly in Malaysia. Agriculture which depends heavily on climate is becoming increasingly vulnerable to risk and uncertainty. In order to face and manage the situation, farmers are trying in various ways and government and other external agencies are providing several supports to adapt to these climatic vulnerabilities. However, there is still a gap between farmers' adaptability and climate change. This study analyses paddy farmers' perception of climatic variations and vulnerabilities and relevant supports and techniques to adapt to the situation. The data were collected through questionnaire survey on 198 paddy producing farmers in the area of Integrated Agricultural Development Area (IADA), North-West Selangor, Malaysia. This study uses descriptive statistics, ordinal regression, percentile, and scale analysis. The study finds that most farmers do not have a clear perception of the climatic changes and vulnerabilities. Farmers' adaptation practices to climatic vulnerability are mostly based on their common sense responses. It suggests that farmers need necessary training and support from the government and international agencies to enable them to effectively adapt to the climatic vulnerability and avert any adverse effect on their socioeconomic sustainability and national food security. Farmers' expectations of several new supports has no statistically significant influences on their current adaptability with climatic changes, but their priority ranking for these expected supports will help policymakers to determine future support for climatic change adaptation for agriculture sustainability and livelihood sustainability under adverse climatic change scenarios, especially for Malaysia.
\end{abstract}

Key words: Agricultural Sustainability; Climate Change; Vulnerability; Adaptation; Farmer; Paddy; Malaysia

\section{Introduction}

The climatic factors have been changing very rapidly in Malaysia. The average temperature in the rice growing areas in Malaysia is about $26^{\circ} \mathrm{C}$. Under current climatic change scenario, temperature above $25^{\circ} \mathrm{C}$ may cause decline in grain mass by $4.4 \%$ per $1{ }^{\circ} \mathrm{C}$ rise in temperature (Tashiro and Wardlaw 1989) and grain yield may decline as much as $9.6-10.0 \%$ per $1{ }^{\circ} \mathrm{C}$ rise (Baker and Allen 1993). Singh et al. (1996) showed that in Malaysia, the actual yield of paddy rice per hectare varied from 3-5 tons, when the potential yield is 7.2 tons. There is a decline of paddy rice yield between $4.6-6.1 \%$ per $1{ }^{\circ} \mathrm{C}$ temperature increase under the present $\mathrm{CO}_{2}$ level. But a doubling of $\mathrm{CO}_{2}$ concentration (from present level of 340-680ppm) may offset the detrimental effect up to $4^{\circ} \mathrm{C}$ temperature increase. In a recent study, it is found that a $1 \%$ increase in temperature leads to a $3.44 \%$ decrease in current paddy yield and $0.03 \%$ decrease in paddy yield in the following season; and a $1 \%$ increase in rainfall leads to $0.12 \%$ decrease in current paddy yield and $0.21 \%$ decrease of paddy yield in the following season (Alam et al. 2010c).

Tisdell (1996) found that rainfall variability increases the level of environmental stress which adversely affects the ability of the system to maintain productivity. It is projected that in Malaysia any change in rainfall, both positive and negative, by more than only $0.4 \%$ by 2020 will cause a decline in paddy yield (NRS 2001). Alam et al. (2011a) indicated that the yearly total rainfall is increasing and its monthly variation is too high. The adverse effects of lower rainfall can be reduced or averted by introducing proper irrigation system. But the effect of 
the opposite phenomenon of over rainfall especially at the end of the crop cycle or at the maturity period is absolutely uncontrollable.

As climatic change is a continuous process, its effects and solutions are also similarly time and efforts consuming processes. Most of the global warming during the next 30 years will be due to emissions that have already occurred (Stern 2007). Due to high greenhouse gas emissions, the temperature is projected to rise by $0.3-4.5^{\circ} \mathrm{C}$. Warmer temperature will cause the sea level to rise by about $95 \mathrm{~cm}$ over a hundred-year period. The changes in rainfall may fluctuate from about -30 to $+30 \%$. This change will reduce crop yield. It may cause drought in many areas so that cultivation of some crops such as rubber, oil palm, and cocoa will not be possible (NRS 2001). NAHRIM projection shows maximum monthly precipitation will increase up to $51 \%$ in Pahang, Kelantan and Terengganu, and the minimum precipitation will decrease by $32-61 \%$ for the entire Peninsular Malaysia. Consequently, annual rainfall will increase by $10 \%$ in Kelantan, Terengganu, Pahang and North-West Coast and decrease by $5 \%$ in Selangor and Johor (NAHRIM 2006). This variation in climatic factors will cause the agricultural system to become vulnerable to risk and uncertainty (Alam et al., 2012e).

In recent years, adaptation has gained prominence as an important response measure especially in vulnerable countries. Even though it has become clear that some impacts are now unavoidable in the short to medium term. Adaptation strategies for the vulnerable groups are crucial because failure to adapt could lead them to suffer from "significant deprivation, social disruption and population displacement and even morbidity and mortality" (Downing et al., 1997). The most critical problem is to identify the appropriate adaptation policies that favour the most vulnerable groups, because stakeholders may not sufficiently be informed about the needs and possible strategies of climate change (Eisenack and Kropp 2006; Eisenack, Tekken and Kropp 2007), farm level faces uncertain future which hinders the development process and poses an obstacle in the implementation of adaptations policy (Behringer et al. 2000; Brown et al. 2007), and the policy deals with different conflicting interest groups. This study analyses paddy farmers' perception of climatic variations and vulnerabilities and focuses on the techniques they use to adapt to the situation. This paper also focuses the adequacy of existing supports for adaptation and the significance of farmers' expectations for new types of supports to adapt to climatic change vulnerabilities.

\section{Data and Methodology}

This study relies on the primary data collected under a research project on economics of climatic change at the Institute for Environment and Development (LESTEARI), National University of Malaysia (UKM). It was funded by the Ministry of Science, Technology and Environment, Government of Malaysia (Alam et al. 2010a). It is a case study of Malaysia's paddy sector. Data were collected through a random sample survey of paddy producing farmers in the eight sections of the Integrated Agricultural Development Area (IADA) of North-West Selangor, Malaysia in 2009.

The survey was conducted by regular enumerators of the IADA authority using a structured questionnaire under the direct supervision of IADA officials. Data were collected from a sample of 198 paddy farmers proportionately distributed among the eight areas. Details of socioeconomic profiles of the respondents are available at Alam and others (2010b,d, 2011c). The data have been analysed under a descriptive and econometric framework using descriptive statistics, percentile, 5-point ordinal scale, and ordinal regression. 


\section{Farmers' Perception of Climatic Vulnerability}

Farmers are the directly affected group and close observers of climatic change and vulnerability (Siwar et al. 2009, Alam et al. 2011b, 2012d). Their understanding about climatic vulnerability largely differs. Overall, $40.9 \%$ of farmers have no proper idea about climatic change and its vulnerability. But $53.3 \%$ of farmers understand climatic vulnerability as the increase in temperature or change in temperature. $55.6 \%$ of farmers understand climatic vulnerability as the unpredictable rainfall or changes in rainfall. For $43.2 \%$ of farmers, it means drought; for $46.5 \%$ of farmers, it is increase in flood. To $53.3 \%$ farmers, rise in sea level is an indicator of climatic vulnerability.

The climatic change causes change in several agricultural relevant factors that determine the sustainability of agricultural production in Malaysia. Farmers believe that vulnerability of some of the factors like injurious insects (supported by $42.9 \%$ of the farmers), temperature (supported by $58.6 \%$ of the farmers), soil fertility loss (supported by $49.5 \%$ of the farmers), and cost of inputs (supported by $61.1 \%$ of the farmers) highly increased over the last 5 years. For some other factors like shortage of rainfall (supported by $45.5 \%$ of the farmers), excessive rainfall (supported by 35.9\% farmers), and labour scarcity (supported by $47.5 \%$ of the farmers) vulnerability increased moderately. Due to the climate change impacts on agriculture, the projections of NAHRIM of paddy yield in terms of climate change, in a given level of temperature and $\mathrm{CO}_{2}$ level, show more than $0.4 \%$ variation of rainfall by 2020 that will cause a fall in paddy yield in Malaysia (NAHRIM 2006). Therefore, the agricultural sustainability in the future in Malaysia is projected to be vulnerable due to climatic changes.

\section{Farmers' Approaches towards Adaptation}

Farmers take various types of measures to adapt with the climatic vulnerabilities. Their approaches vary based on their perceptions, knowledge, locations, availability of resources, cropping patterns, nature and degree of vulnerability, etc. (Alam et al. 2012d).

In the case of excessive rainfall, farmers pump out water from the paddy fields. Nearly $44 \%$ of farmers add more water in the field for maintaining the required moisture level during the time of high temperature or sunshine. However, in the case of low rainfall, farmers do not have proper ideas on how to cope with the situation. As IADA provides the irrigation facilities, farmers are fully dependent on IADA for irrigation.

To cope with soil fertility losses, $40.4 \%$ of the farmers use organic fertilizer, $24.7 \%$ use lime, and $15.2 \%$ use chemical fertilizer. When weeds grow on the crop field, farmers cut the weeds or use weedicide. To cope with the insect and paste attacks, $83.8 \%$ of farmers mostly rely on using chemical fungicide and pesticide. Some of them try to seek solution to the problem through natural processes such as by changing the crop planning schedules.

Farmers' adaptation practices to cope with the agricultural vulnerability due to climatic change are not found adequate and satisfactory (Alam et al. 2011d, 2012a,c). Their adaptation methods are based only on their ideas or reactions. As a result, only $30.3 \%$ of the farmers believe that they have been able to properly cope with climatic vulnerabilities (Alam et al. 2012d).

\section{Current Supports to Climate Change Adaptation}


On the issue of availability of external supports, most of the farmers were found to be not aware of the current supports provided by external parties to adapt to climate change. But, in order to support the farmers to increase productivity and increase income, government's subsidy for agricultural sector is increasing each year (Alam et al. 2012a,c). The subsidies for urea and compound fertilizer have been continuing since 1979. The incentives for land preparation and using organic fertilizer have been continuing since 2007. Providing the package of compound and urea fertilizers and pesticide incentives was introduced in 2008 and is still continuing. 58.6\% of the farmers agreed that government supports are enough to cope properly with climate change. But still $12.1 \%$ reported that they cannot cope with climate change with the current level of external supports. $52.5 \%$ of farmers mentioned about the supports from NGOs, and 49.5\% mentioned about the supports from other external agencies to be enough to cope with current climate change. However, NGOs provide very little support. Their support includes small scale training and experimental plots to test the productivity rate.

According to $75.3 \%$ of the farmers, the fertilizer provided by the government was enough for paddy production. This indicates that these farmers never use extra fertilizer except the fully subsidized quantity. The statistical output shows farmers significantly believe that buying additional fertilizer from the market is not important for their adaptation ability with climate change (Alam et al. 2011d).

Under the IADA, the most influential external supports were the same for all the farmers, such as government subsidy and incentives. Therefore, the influences of these supports on farmers' adaptation capacity were the same for all. Only for the access in market - indicates buying fertilizer, pesticides and other necessaries from market - differed from farmers to farmers which showed significant impacts on farmers' ability to adapt to climate change (Alam et al. 2011d).

\section{Required Supports to Climate Change Adaptation}

Still farmers expect several types of external supports to cope properly with the changes in climatic factors. Among several types of expected new supports, based on statistical test, farmers significantly believe moisture deficiency related innovations, crop development, cash incentive, infrastructural supports, and adjustment in wage, and leasing system are required to adapt to climate change (Alam et al. 2012a,c).

As the needs differ from farmer to farmer, more in-depth and specific requirement is possible to measure by categorical and individual type of variable analysis. Among all types of resource management innovations, $70.7 \%$ of the farmers expect water management innovation, $72.2 \%$ of the farmers emphasize on the need for moisture deficiency protection innovations, $68.7 \%$ emphasize on the development of new crops or finding out varieties of crops, or innovation of climate change tolerant crops to cope with changing climate.

Among different types of information related supports, better information system for early warning about changes in climate factors is considered important by $80.8 \%$ of the farmers. Moreover, $72.2 \%$ of the farmers agree that weather forecast is important to adapt to climate change. The highest numbers of the farmers $(80.8 \%)$ emphasize on the importance of proper guidelines and suggestions to adapt to climate change properly. 
Among the financial and other relevant external supports from government, NGOs and other local and international agencies, $79.8 \%$ of the farmers feel the necessity for raw materials subsidy and cash incentive, and $78.3 \%$ emphasize on insurance supports or minimum income ensuring supports to adapt to climate change. Among different encouraging relevant supports, $78.8 \%$ of the farmers agree about the necessity of infrastructure related supports.

Among the production practices related supports, $51 \%$ of the farmers consider diversifying crop types and varieties of crops are needed, and $71.7 \%$ emphasize on importance of land usage pattern to cope with climate change. Moreover, $73.2 \%$ of the farmers mention that the leasing system and agricultural wage are important, and $71.2 \%$ of the farmers think that merger of individual farmers into single-large farms is also necessary to adapt to climate change vulnerability.

Among different types of external supports, the farmers setup the priority of supports based on the perceived importance of each categorical support to adapt to climate change. Farmers firstly need financial and encouraging supports (agreed by 41.9\%). Secondly, they need information related supports (agreed by 32.3\%). Thirdly, they need resource management innovation related supports (agreed by 31.3\%). Fourthly, they need crop development related supports (agreed by 33.8\%). Finally, they need production practice related supports (agreed by $43.4 \%$ ). The priority setup is based on the highest number of choice for each category, which differs among farmers based on individual necessities. But farmers' expectations of several new supports has no statistically significant influences on their current adaptability with climatic changes, but their priority ranking for these expected supports will help policymakers to determine the future supports for climatic change adaptation for agriculture sustainability and livelihood sustainability under adverse climatic changes scenarios, especially for Malaysia (Alam et al. 2012a,c).

\section{Conclusion and Recommendations}

The study finds that most paddy farmers do not have a clear perception of climatic change and vulnerability. Most farmers understand that increases in drought, flood, and sea level are the results of climatic changes. To cope with the situation and avert any adverse effect, farmers are trying various methods to adapt to the changes in various climatic factors. However, these methods are not found to be very effective. As a result, the agricultural sector of the country is becoming increasingly vulnerable, threatening farmers' livelihood sustainability and national food security (Alam et al. 2011e).

To enable farmers to adapt to climate change, the very first important step required is to make them aware of future risks of climate change, especially climate change related socioeconomic vulnerabilities. It will help them prepare their mindset to deal with climate change and other socioeconomic stresses and think about how to respond in adverse situations. Moreover, the production practices of farms and individual farmers are needed to be kept up to date with the changes in climatic factors. They should also take all precautions and be aware of the uncertainty of low rainfall and heavy rainfall. They must be careful in arranging proper water management, both in terms of irrigation facilities and quick water logout facilities. Apart from that, they also need to understand the importance of proper timing and react quickly at the sight of upcoming rainfall events. Paddy farmers in the study area, therefore, need necessary training and support from the government and the international agencies for better adaptation to climatic vulnerabilities (Alam et al. 2010e, 2012b). 
The financial management of farms and farmers too needs to be secured for a minimum of two seasons so that if the crop is damaged in one season, they will be prepared and have the seeds for the next season; their ability to bear the cost of another crop production will guarantee their survival by being financially sustained until the collection of the new crops. Currently, heavy rainfall and storm are a very common phenomenon in the study area. For that reason, farmers should take the initiative for crop sharing, forward rating, hedging and insurance. Farmers also need crop insurance facilities, but no such option is currently available. Moreover, they need to take income stabilization programmes, such as portfolio of investment, saving scheme, minimum income protection by government or insurance to reduce the risk of income loss due to changing climatic conditions and variability. The respected authorities also need to check the significance of the necessity of farmers' expectations of new supports from time to time to take appropriate steps and support the affected farmers. At last, it has been suggested to prepare a planned and proactive adaptation strategy in Malaysia to secure a sound functioning of the economic, social and agricultural system.

\section{Acknowledgement}

We are thankful to Ministry of Science, Technology and Environment of the Government of Malaysia for generously funding the research, under the Research University Grants (UKMAP-PLW-04-2010, LRGS-TD-2011-UPM-UKM-KM-04 and UKM-GUP-PI-08-34-081). We would also like to thank Dr. Basri Talib, Dr. Mohd Ekhwan bin Toriman, Prof Dr. Abdul Hamid Jaafar (National University of Malaysia), Md. Wahid Murad (University of Adelaide, Australia), and Prof. Dr. Rafiqul Islam Molla (International Islamic University Chittagong, Bangladesh) for their advices and supports at various stages of the study.

\section{References}

Alam MM, Siwar C, and Toriman ME (2010a) Socioeconomic Study of Climate Change: An Assessment of Agriculture and Livelihood Sustainability on Paddy Farming in Malaysia. LAP Lambert Academic Publishing, Saarbrucken.

Alam MM, Siwar C, Murad MW, Molla RI, and Toriman ME (2010b) Socioeconomic Profile of Farmer in Malaysia: Study on Integrated Agricultural Development Area in NorthWest Selangor. Agricultural Economics and Rural Development 7(2):249-26. ftp://www.ipe.ro/RePEc/iag/iag_pdf/AERD1013_249-265.pdf Cited 05 Nov 2012

Alam MM, Talib B, Siwar C, and Toriman ME (2010c) The Impacts of Climate Change on Paddy Production in Malaysia: Case of Paddy Farming in North-West Selangor. Proceedings of the international conference of the 4th International MalaysiaThailand Conference on South Asian Studies. National University of Malaysia, Malaysia, Mar 25-26.

Alam MM, Siwar C, Molla RI, Toriman ME, and Talib B (2010d) Socioeconomic Impacts of Climatic Change on Paddy Cultivation: An Empirical Investigation in Malaysia. Journal of Knowledge Globalization 3(2):71-84. http://journals.sfu.ca/jkg/index.php/journal/article/view/57/44 Cited 05 Nov 2012

Alam MM, Siwar C, and Al-Amin AQ (2010e) Climate Change Adaptation Policy Guidelines for Agricultural Sector in Malaysia. Asian Journal of Environmental and Disaster Management 2(4):463- 469. DOI 10.3850/S1793924011000873 Cited 05 Nov 2012 
Alam MM, Toriman ME, Siwar C, and Talib B (2011a) Rainfall variation and changing pattern of agricultural cycle. American Journal of Environmental Science 7:82-89. DOI 10.3844/ajessp.2011.82.89 Cited 05 Nov 2012

Alam MM, Siwar C, Molla RI, Toriman ME, and Talib B (2011b) Climate Change and Vulnerability of Paddy Cultivation in North-West Selangor, Malaysia: A Survey of Farmers' Assessment. Voice of Academia 6(1):45-56.

Alam MM, Siwar C, Talib B, and Toriman ME (2011c) An Empirical Study on the Relationships between the Socioeconomic Profile of Farmers and Paddy Productivity in North-West Selangor, Malaysia. Asia-Pacific Development Journal 18(1). http://www.unescap.org/pdd/publications/index_apdj.asp Cited 05 Nov 2012

Alam MM, Toriman ME, Siwar C, Molla RI, and Talib B (2011d) The Impacts of Agricultural Supports for Climate Change Adaptation: Farm Level Assessment Study on Paddy Farmers. American Journal of Environmental Sciences 7(2): 178-182. DOI 10.3844/ajessp.2011.82.89 Cited 05 Nov 2012

Alam, MM, Siwar C, Murad MW, and Toriman ME (2011e) Impacts of Climate Change on Agriculture and Food Security Issues in Malaysia: An Empirical Study on Farm Level Assessment. World Applied Sciences Journal 14(3): 431-442. http://idosi.org/wasj/wasj14(3)11/12.pdf Cited 05 Nov 2012

Alam, MM, Siwar, C, Mohd Ekhwan, T, Molla, RI, and Talib, B (2012a) Climate Change Induced Adaptation by Paddy Farmers in Malaysia, Mitigation and Adaptation Strategies for Global Change 17(2): 173-186. http://www.springerlink.com/content/w443477600871315/ Cited 05 Nov 2012

Alam, MM, Siwar, C, Talib, B, Mokhtar, M, and Mohd Ekhwan, T (2012b) Climate Change Adaptation Policy in Malaysia: Issues for Agricultural Sector, African Journal of Agricultural Research 7(9): 1368-1373. http://www.academicjournals.org/ajar/PDF/pdf2012/5\%20Mar/Alam\%20et\%20al.pdf Cited 05 Nov 2012

Alam, MM, Siwar, C, Talib, B, Jaafar, AH, and Mohd Ekhwan, T (2012c) Farmers' Perceptions Study on Required Supports for Climate Change Adaptation in Malaysia, Asian Journal of Environmental and Disaster Management 4(1): 83-97. http://www.rpsonline.com.sg/journals/101ajedm/2012/0401/S179392402012001081.php Cited 05 Nov 2012

Alam, MM, Siwar, C, Molla, RI, Talib, B, and Mohd Ekhwan, T (2012d) Paddy Farmers' Adaptation Practices to Climatic Vulnerabilities in Malaysia, Mitigation and Adaptation Strategies for Global Change 17(4): 415-423. http://www.springerlink.com/content/31427ppr79181715/ Cited 05 Nov 2012

Alam, MM, Morshed, G, Siwar, C, Murad, MW (2012e) Initiatives and Challenges of Agricultural Crop Sector in ECER Development Projects in Malaysia, AmericanEurasian Journal of Agricultural \& Environmental Science 12(7): 922-931. http://idosi.org/aejaes/jaes12(7)12/12.pdf Cited 05 Nov 2012

Baker JT, Allen JrLH (1993) Contrasting crop species responses to $\mathrm{CO}_{2}$ and temperature: rice, soybean and citrus. Vegetatio 104/105: 239-260. http://www.jstor.org/pss/20029749 Cited 05 Nov 2012

Behringer J, Buerki R, and Fuhrer J (2000) Participatory integrated assessment of adaptation to climate change in Alpine tourism and mountain agriculture. Integrated Assessment 1:331-338. DOI: 10.1023/A:1018940901744 Cited 05 Aug 2011

Brown K, Few R, and Tompkins EL (2007) Climate change and coastal management decisions: insights from Christchurch Bay, UK. Coastal Management 35(2-3):255270. DOI: 10.1080/08920750601042328 Cited 05 Aug 2011 
Downing, TE, Ringius, L, Hulme, M, and Waughray, D (1997) Adapting to climate change in Africa. Mitigation and Adaptation Strategies for Global Change 2:19-44. DOI: 10.1023/B:MITI.0000004663.31074.64 Cited 05 Aug 2011

Eisenack K, and Kropp J (2006) Regional stakeholder perceptions of climate change: Baltic case study screening. ASTRA document, Potsdam. http://www.pikpotsdam.de/ eisenack/downloads/CSSreport-fd.pdf Cited 05 Aug 2011

Eisenack K, Tekken V, and Kropp J (2007) Stakeholder Perceptions of climate change in the Baltic Sea Region. Coastline Reports 8:245-255. http://spicosa.databases.euccd.de/files/documents/00000816_Eisenack_Tekken_Kropp.pdf Cited 05 Aug 2011

NAHRIM (2006) Final Report: Study of the Impact of Climate Change on the hydrologic Regime and Water Resources of Peninsular Malaysia, National Hydraulic Research Institute of Malaysia (NAHRIM) and California Hydrologic Research Laboratory (CHRL),

Malaysia. http://www.nahrim.gov.my/download/pksa/RegHCM_PM_Report_9_21_06_Ex\%20v 1.pdf Cited 05 Aug 2011

NRS (2001) National Response Strategies to Climate Change. Ministry of Science, Technology and the Environment, Malaysia. http://gedung.nahrim.gov.my/wapi/mctweb.dll/getObject?MID=WATER\%20RESOU RCES\&Sn=2038 Cited 05 Aug 2011

Singh S, Amartalingam R, Wan Harun WS, and Islam MT (1996) Simulated impact of climate change on rice production in Peninsular Malaysia. Proceeding of National Conference on Climate Change. p 41-49, UPM, Malaysia.

Siwar C, Alam MM, Murad MW, and Al-amin AQ (2009) A review of the linkages between climate change, agricultural sustainability and poverty in Malaysia. International Review of Business Research Papers 5(6):309-321. http://www.bizresearchpapers.com/23.\%20Siwar.pdf Cited 05 Nov 2012

Stern N (2007) The Economics of Climate Change: The Stern Review. Cambridge University Press, Cambridge.

Tashiro T, and Wardlaw IF (1989) A comparison of the effect of high temperature on grain development in wheat and rice. Annals of Botany 64:59-65.

Tisdell C (1996) Economic indicators to assess the sustainability of conservation farming projects: An evaluation. Agriculture, Ecosystems and Environment 57(2):117-131. 